International Journal of Social Science And Human Research

ISSN(print): 2644-0679, ISSN(online): 2644-0695

Volume 04 Issue 04 April 2021

DOI: $10.47191 / \mathrm{ijsshr} / \mathrm{v} 4-\mathrm{i} 4-15$, Impact factor-5.586

Page No : 678-684

\title{
The Politico-Criminal Configuration Relationship between Organized Crime and the State as a Form of State-Organized Crime in the Phenomenon of Production and Circulation of Counterfeit Drugs in Indonesia
}

\author{
Bismo Teguh Prakoso', Adrianus E. Meliala ${ }^{2}$, Arthur Josias Simon Runturambi ${ }^{3}$ \\ ${ }^{1}$ Doctor from the Department of Criminology at the University of Indonesia and member of the Indonesian National Police as the \\ Police Chief of the Ciamis Resort. \\ ${ }^{2}$ Professor from the Department of Criminology, University of Indonesia \\ ${ }^{3}$ Chair of the University of Indonesia National Resilience Study Program and is also a permanent lecturer at the Department of \\ Criminology at the University of Indonesia
}

\begin{abstract}
Counterfeit drugs in Indonesia had reached two billion USD or $25 \%$ of total amount pharmaceutical business in Indonesia during 2016 (MIAP, 2016). Preventive and repressive effort have been endeavored across sectors of formal institution. Nevertheless, the business remain stay. In my opinion, this situation may have supported by the existance of politicocriminal configurations, a symbiosys mutualism interaction between holders of political power (state) dengan users of extralegal force and intimidation (organized crime) Briquet \& Favarel-Garrigues, 2010). Through qualitative approach, this study interviewed state apparatus from seven drugs related enforcement institions and two offenders. Result shows relation of politico-criminal configurations is not fully proven. This relation is only found in the form of co-optation of state functions as enforcement of norms by organized crime through corrupted state apparatus. Furthermore, study also find that a complicated business process of drugs creates a criminogenic environment that is supported by corporate-organized crime.
\end{abstract}

KEYWORD: politico-criminal configurations, organized crime, corporate organized crime, state-organized crime

\section{INTRODUCTION}

Counterfeit drugs can be identified or found in the chain of production, distribution, and consumption. Based on data published by the Indonesian Anti-Counterfeiting Society (MIAP) in 2016, counterfeit drugs in Indonesia account for $25 \%$ of the Indonesian drug business, which amounts to $\$ 2$ billion. Counterfeit drugs are also starting to be marketed online. Apart from the risks of obtaining fake drugs, shopping for drugs online provides various benefits such as getting drugs that are hard to find in the market and, of course, lower prices. From 30 May to 7 June 2016, Indonesia secured thousands of illegal drug packaging worth 4.2 million US dollars. Thousands of fake drugs are secured from 64 factories and production sites throughout Indonesia. At the same time, as many as 214 sites selling fake drugs were also forced to close (Kartika, 2017).

Given that the terminology of fake drugs is often used interchangeably and overlaps with other terminologies, such as illegal drugs or illicit drugs, it is necessary first to examine the definition of fake drugs. The World Health Organization (WHO) has defined counterfeit medicine as "one which is deliberately and fraudulently mislabeled with respect to identity and/or source. Counterfeiting can apply to both branded and generic products and counterfeit products may include products with the correct ingredients or with the wrong ingredients, without active ingredients, with insufficient active ingredients or with fake packaging" (Davison, 2011).

WHO also identified that " 16 percent of counterfeit drugs contain the wrong ingredients, 17 percent contain incorrect amounts of the proper ingredients, and 60 percent have no active ingredients whatsoever" (Treverton, dkk., 2009).

Indonesia, with the fourth largest population in the world, is a potential market to reap abundant profits. The inability of the government to meet the high needs of the public for cheap and quality drugs is a business opportunity for business people. This opportunity is then used by businesses to produce drugs illegally to reap huge profits, as explained by Zhou (2005) "as the profits from selling a counterfeit drug can be as high as the sale of illegal narcotics, organized crime has become involved in the counterfeit drug product industry" (Zhou, 2005). 


\section{The Politico-Criminal Configuration Relationship between Organized Crime and the State as a Form of State- Organized Crime in the Phenomenon of Production and Circulation of Counterfeit Drugs in Indonesia}

Profits from this illegal business can reach tens of billions of rupiah per month. A right business person indeed considers all conditions such as a small risk when dealing with law enforcement. In this context, Zhou (2005) also writes "said that organized crime faces less risk in moving into counterfeit medicine than illegal drugs" (Zhou, 2005).

The production and distribution of counterfeit drugs have far more significant economic benefits than the production of narcotics or psychotropic substances, and the risk of imprisonment and penalties is far less than narcotics / psychotropic crimes. Raw materials for fake drugs are also natural to obtain, as are used production machines, packaging materials that closely resemble the original product are not difficult to recognize with technological advances today. As stated by Cole et al. (2013) Organized crime groups are active in the trafficking of counterfeit prescription drugs because it can be an extremely profitable business (Cole, dkk., 2003).

The government still has limitations in providing cheap and high-quality medicines that are needed by the community. Government policies on drugs, production restrictions for certain drugs, licensing is stringent and felt difficult. It makes the price of drugs in Indonesia more expensive when compared to neighbouring countries.

The profit gained from the production and distribution of fake drugs can reach tens of billions of rupiah. The risk of the threat of imprisonment, as well as fines, is felt far less than narcotics crime. The whole situation is ultimately exploited by perpetrators of crimes, one of which is organized crime groups, in producing these drugs illegally to meet market demand.

The existence of organized crime groups in a country is still a subject of discussion and research. Primarily if its emergence is often associated with corrupt practices, globalization, and transnational aspects, according to Shelley (2007), organized crime sees that the opportunity to obtain economic benefits can only be obtained if it collides with state officials. The corrupt government, in this case, is needed to guarantee its survival. Organized crime then infiltrates the state, while at the same time obtaining protection from the government, including law enforcers. Bezlov and Gounev (2012), in line with Shelley (2007), explained the use of corruption by organized crime as a tool to influence politicians, state government officials, police, justice, and customs (Edelbacher et al., 2016).

The growing development of organized crime also marks the impact of state policies on regulating the process of production and distribution of goods and services needed by citizens. Organized crime often exploits the weaknesses of state policy or co-opts the state in collusive and corrupt ways (Kleiman and Smith, 1990; Benson, Rasmussen and Sollars, 2000; Morris and Stevens, 2006). Countries that should pay attention to the right to health, including through policies on the production and distribution of drugs, by providing medicines that are cheap, affordable, accessible, and of high quality, have, in fact, not been able to realize them. In addition to questioning the factors that cause state policies to fail, several studies are still trying to identify and question the linkages between state policies and organized crime (Correa-Cabrera, Keck, \& Nava, 2015).

Some research that refers to the relationship between the state and organized crime groups can be found in Kleiman and Smith (1990). Kleiman and Smith (1990) show that the relationship between the state and organized crime groups can be seen when the state is not only incapable, but it is deliberately not severe and tends to allow policing of organized crime. Relationships between countries and organized crime groups can also be referred to in Morris and Stevens (2006). Morris and Stevens (2006) explain that the existence of state involvement can be seen from the inability of the state to make laws or regulations that are strong. Legislation or regulations are not really made to protect citizens from threats or losses that arise as a result of practices carried out by organized crime groups.

\section{METHOD}

The approach used in this study is qualitative. The qualitative approach places the researcher's position to think inductively in answering research questions, namely capturing social phenomena that occur in the field first then attempting to do theorization based on what he observes. According to Strauss and Corbin (1998), in his book "Fundamentals of Qualitative Research," qualitative research can also be intended as a type of research whose findings are not obtained through statistical procedures or other forms of calculation (Strauss \& Corbin, 1998). Syaodih (2006), in his book "Action Research Method," also explains that qualitative research departs from the philosophy of constructivism, which assumes that reality has multiple dimensions. Qualitative research is interactive and involves the exchange of social experiences (a shared social experience) interpreted by individuals (Syaodih, 2006). To explain how the relations between politico-criminal configurations that occur between the state and organized crime, the authors choose a qualitative approach. The qualitative approach is not only used as a data collection method, but also data analysis. The analysis of this research starts from the phenomena of producing and distributing fake drugs, abstracting them into the concept of organized crime activities, then gathering relevant concepts, and then compiling them into an explanation of the relationship between politicocriminal configurations. Based on its usefulness, this research is classified into basic research considering the research and research results are used to improve understanding of basic knowledge about a phenomenon. Based on the purpose of the research, this research is classified into explanation research; namely, this research provides explanations about the sources of politicocriminal configurations, including documenting the causes. 
The Politico-Criminal Configuration Relationship between Organized Crime and the State as a Form of StateOrganized Crime in the Phenomenon of Production and Circulation of Counterfeit Drugs in Indonesia

\section{RESULTS AND DISCUSSION}

\section{Counterfeit Drugs, State, and Organized Crime}

One of the causes that can be explained related to the existence of organized crime in the drug business process chain is the length of the business process of the drug industry in Indonesia, from the production process, distribution, to consumption. A long business process causes organized crime to have the opportunity to be able to carry out its activities in each stage of the drug business process. Therefore, it is not surprising that organized crime is carried out, carrying out criminal activities in the form of manipulation of content composition, expiration date, packaging, including up to price manipulation and sales strategies.

A long business process, involving much capital, loaded with regulations, bound by technical aspects, complex stages, and involving many stakeholders makes the business process of the drug industry has potential, referring to the explanation of Friedrichs (2010) when observing a long business process, as criminogenic environment, which is a place that is very conducive and potential for crime. The method generally carried out by organized crime when infiltrating into a long drug business process is by carrying out a series of fraudulent, counterfeiting, embezzlement, and bribery activities through various modus operandi (Kelly, 1999; Scheb \& Scheb II, 2011).

In addition to the criminogenic drug business process chain, organized crime activities in the drug business process that show an increasing trend every year are very likely also caused by an increasingly competitive market mechanism, weakened social control, and globalization. As part of social change and social transformation, these factors open up opportunities for committing crimes by organized crime at the national and global levels (Karstedt \& Bussmann (Eds.), 2000). He also added that the global economy is run by elites who operate internationally but have close links in business, politics, and bureaucratic networks (in the context of the drug business process, these elites are countries and industries or large drug companies). This condition forms a relationship called patrimonial-feudal patterns. Along with the global economic network, organized crime activities appear and tend to increase because organized crime has the same roots and tends to be able to adapt to these patrimonial-feudal patterns (Karstedt and Bussmann (Eds.), 2000).

Organized crime also can create or make an area conducive and suitable for him. Organized crime can use the power or power possessed. Power or power can be divided into:

1. Coercive power or power over, by systematically enforcing absolute values through institutional practices, to cover their interests (Bachrach \& Baratz, 1970).

2. Influential power, by exploiting its position in the network and using it to manipulate pressure and change certain events for desired results. Bribery of public officials, falsification of documents, manipulation of rules, control of the market, and regulation of political agendas are typical modus operandi (Walters, 2011).

3. Soft power or ambassadorial power, using charm, persuasion, and entrepreneurship, presenting, building, and promoting the results they want through methods and images that seem to support the interests of many parties. Tombs and Whyte (2010) call it covert power.

Indonesia, as an ideal equilibrium for counterfeit drug business, is also supported by Indonesia's position, which is still a developing country. Like other developing countries, the economic sector is a priority sector compared to other sectors. The obstacles that will have an impact on the development of the domestic economy are of concern to the government. This is evidenced by President Joko Widodo's priority policy to cut down the various complicated bureaucratic processes that interfere. One of them is like a policy in the Customs region, which cuts down the bureaucratic process there so that the import and export process is carried out faster. This situation benefits the fake drug business in Indonesia.

Looking at the types of drugs commonly falsified by organized crime, such as cholesterol-lowering drugs, gout medications, pain or pain-relieving drugs, and vitality enhancing drugs, this shows that medicine for the community is functioned as a tool to maintain health, prevent disease, treat disease, and overcome death (Bradby, 2009). Medicine is a critical player in the business or the health industry, which immediately puts it in the middle of a negotiating process that is routinely held. Drugs are also often in contention and disagreement between interest groups, such as citizens, patients, politicians who formulate policies, health professionals, including management and doctors, and regulatory bodies, such as the POM.

The state, then, in this case, puts and sees medicine as one of the essential services and has an essential role in welfare. Also, the state sees that medicine has an essential role in producing a whole generation in the future. Furthermore, the state is also aware and well aware of the side effects contained in the drug. Therefore, it is natural that the state then exercises its function in carrying out planning and direction by establishing laws, regulations, decisions and so on which in essence provide or provide guidance in each node of the drug business process (Pisano, 2003), complete with the formulation of sanctions and penalties and its state apparatus if a violation of the laws, regulations, and decisions are made.

The emergence of laws, regulations, and state decisions governing drugs, and immediately led to the criminalization, violations referred to as crimes, and violators against them referred to as criminals, and as a logical consequence, the emergence or efforts of 
The Politico-Criminal Configuration Relationship between Organized Crime and the State as a Form of StateOrganized Crime in the Phenomenon of Production and Circulation of Counterfeit Drugs in Indonesia

policing. However, in reality, the police effort carried out is not an easy thing. The main obstacle in policing crime is the low ability of the police to conduct and identify events, for example, distinguishing original drugs from fake drugs, identifying clandestine operations, shell companies, as a phenomenon of crime committed by organized crime (Gottschalk, 2014). This is because, for example, the police are unable to view and consider available sources of information and information, and have not been able to develop networks with individuals in the critical area. The critical area referred to in this case is the ins and outs of the business process of counterfeiting drugs and the stakeholders involved in conducting policing. It should be remembered that until now, the police still depend on expert witnesses in finding criminal elements.

Rather than as an effort to provide services and protection for citizens, in reality, the implementation of laws, regulations, and decisions made by the state actually causes limited access of citizens to obtain drugs (Ho, 2011). At the very least, drug business processes that are regulated into capital-intensive business processes lead to expensive drug prices (Davis \& Abraham, 2013; Bhaskarabhatla, 2018). It is true that laws, regulations, and decisions formulated by the state regarding drugs are made very rigid, given the side effects of drugs for humans. However, on the other hand, it turns out that the existing laws, regulations, and decisions are seen as opening more opportunities and accommodating to the interests of large drug companies that have significant capital. In addition, the state also seems unable to properly place demands for respect for international agreements on patents and related rights in formulating laws, regulations, decisions. (Ho, 2011). Limited access to drugs raises demand and becomes a new market, which is then exploited by organized crime by providing fake drugs (Ho, 2011).

In addition to the three things above, several cultural and socio-economic conditions are needed for organized crime to survive. First, organized crime needs to compile and follow specific operational tactics to maintain the sustainability of the organization and its illegal activities (diverse and changing modus operandi, even buying raw materials from original drug companies). Second, organized crime leaders tend to carry out their leadership functions in ways that are not visible or obvious (absentee fashion). Even though the informant stated that there was a leader in the group, it was not sure that the intended person was the leader at the peak of the organized crime. Third, members of organized crime also try to be able to maintain their identity, try to be low-profile, and try to avoid getting involved in the slightest legal problem (Huang, 2008). With this condition, organized crime realizes that it is not safe to build an organizational base and carry out business activities in developed industrial countries. Finally, they choose to run their organizations and activities in developing or economically underdeveloped countries.

\section{Relations between the State and Organized Crime: Discussion and Synthesis}

The idea that there is a relationship between the state and organized crime in the concept of politico-criminal configurations (Briquet \& Favarel-Garrigues, 2010; Gayer, 2014; Ketchley, 2017) does not seem to be fully proven in this study. Data, interpretation, and analysis have not been able to find and confirm indications of such a relationship in the fake drug business process in Indonesia. However, this study identifies the existence of organized crime in the drug business process in Indonesia and Indonesia as a country that has strategic value for organized crime in carrying out drug counterfeiting activities. Data, interpretation, and analysis also found the involvement and role of the state apparatus (Customs, BPOM, and police) in the fake drug business process carried out by organized crime.

Data, interpretation, and analysis can only confirm several aspects related to the existence of organized crime activities in the fake drug business process in Indonesia. The description of the results of this study can be seen as follows:

\section{Picture 1. Concepts Relation in Counterfeit Drugs in Indonesia}

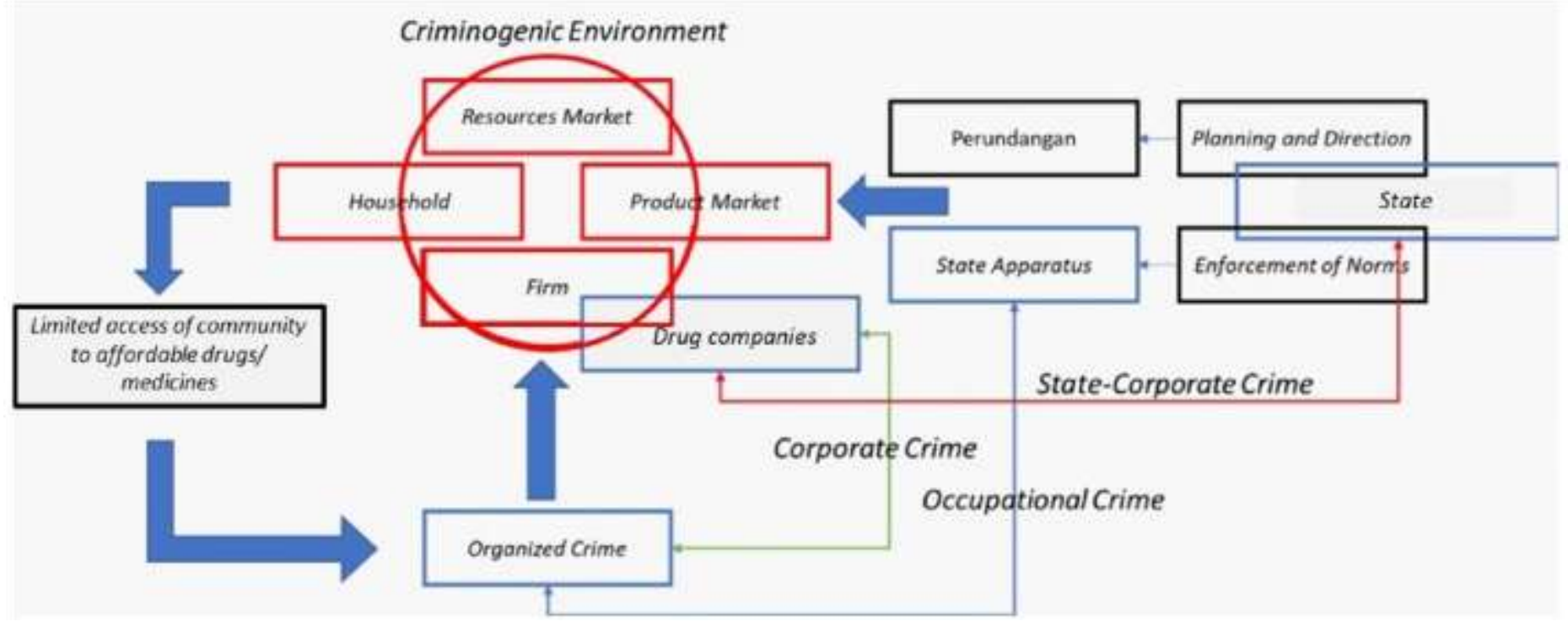




\section{The Politico-Criminal Configuration Relationship between Organized Crime and the State as a Form of State- Organized Crime in the Phenomenon of Production and Circulation of Counterfeit Drugs in Indonesia}

First, laws, regulations, decisions made by the state, complete with its state apparatus make the drug business process a long business process, tend to open more opportunities, and accommodate the interests of large drug companies, and have not been able to lay with Appropriate demands for respect for international treaties on patents and related rights which in the end makes the public's access to cheap drugs limited. In this context, the state can be defined as having committed a state crime (Walker, 2005; Michalowski, 2010), not only ignoring citizens' rights to health but also not being able to protect citizens from the emergence of risks in the form of illness or death caused by drug consumption false. On the other hand, the existence of large drug companies that can co-opt the functions of the state and carry out planning and direction with their interests when formulating laws, regulations, and decisions regarding the business process of drugs by bribery shows that there is a relationship between the state and large drug companies known as terminology or the concept of state-corporate crime.

Secondly, laws, regulations, and decisions made by the state make the drug business process lengthy and make the business process a criminogenic environment. The legislation is traditionally intended to be part of the social control of crime (Innes, 2003). The existence of legislation relating to an issue is fundamental to be seen because at least it plays a role in (Head, 2005): (1) criminalize an act; (2) give a threat of punishment for violations; (3) the existence of levels of the threat of punishment by the seriousness and impact caused by an act; (4) certain parties should recover victims.

However, in the context of legislation, regulations, decisions made by the state regarding the drug business process, this, in turn, has an impact on the limited access of citizens to obtain drugs. These situations and conditions are then exploited as a market and opportunity by organized crime to make a profit.

Third, efforts to organize crime for profit are also facilitated by the weak role of state apparatus policing (Customs, BPOM, and police) when dealing with coercive power, influential power, or soft power possessed by organized crime. This explains that the evil relations that surfaced then were fraud, embezzlement, bribery, corruption, and abuse of authority (occupational white collarcrime). This also explains the weak implementation and enforcement of laws, regulations, and state decisions concerning the drug business process. At the same time, it can also be understood if organized crime, in this context, is reluctant to influence laws, regulations, state decisions about the drug business process, considering that it will be too expensive and considered to have no competitive advantages.

Fourth, the same power is also used by organized crime when importing or obtaining raw materials for processing into fake drugs (service companies, official drug importers, or original drug producers). In this context, relationships that emerge can then classified as corporate crime.

The relation of politico-criminal configurations, as a concept as conceived by Briquet \& Favarel-Garrigues (2010), Gayer (2014) and Ketchley (2017) seems not to have been fully formed or at least not seen if seen in the context of the setting of drug counterfeiting activities committed by organized crime. Organized crime does not directly access the state but through an intermediary, namely the state apparatus. This can be explained:

1. The state does not have an enemy that interferes with its power and ability to maintain social order, even if the enemy exists, it seems that the state does not yet need help from organized crime to overcome these enemies.

2. To maintain or maximize profits and to survive, an organized crime requires protection, including political protection. However, this protection is sufficient to obtain by establishing relations with the state apparatus rather than establishing direct relations with the state.

3. State and organized crime do not have a common enemy.

From the explanation above, then it refers to organized crime that conducts drug counterfeiting activities that have specific characteristics, namely:

1. Tend to avoid the use of violence, preferring to use influential power.

2. Tend to choose members who are known to be close and can be trusted.

Based on the discussion and analysis, it answers the second working hypothesis where the state is actively or by the commission in cooperation with organized crime, apparently not visible. Because this relationship is formed because of the existence of a state apparatus, so the form of politico-criminal configurations in the counterfeit drug business in Indonesia is imperfect. Only one state function has been co-opted by the organized crime group, namely the function of enforcement of norms.

While answering the third working hypothesis in which politico-criminal configurations between the state and organized crime harm consumers, it is answered that the relationship between político-criminal configurations that formed even though imperfect turned out to still support the sustainability of the fake drug business in Indonesia. The danger posed is the increasingly widespread and mushrooming influence of organized crime groups in meeting the demand for cheap drugs from the public while the public is harmed and threatened with safety because of consuming drugs that are not in accordance with the standards or drugs that have expired. 
The Politico-Criminal Configuration Relationship between Organized Crime and the State as a Form of StateOrganized Crime in the Phenomenon of Production and Circulation of Counterfeit Drugs in Indonesia

\section{CONCLUSION}

The analysis of the findings data shows that the relationship político-criminal configuration in the context of the fake drug business can occur if it meets the following conditions; (1) Access to cheap medicines which is limited and cannot be fulfilled by the state; (2) A criminogenic environment found in a long drug business process; (3) Politicocriminal configurations are supported by corporate-organized crime. This can then answer the working hypothesis that the político-criminal configurations relations formed in the fake drug business in Indonesia are imperfect because the organized crime group has successfully coopted only one state function while the other functions are still running well. Even so, responding to the third working hypothesis, the danger posed by the relations of políticocriminal configurations in the counterfeit drug business not only has an impact on the increasingly widespread influence of organized crime groups in influencing the state and also the expanding power of organized crime in controlling the drug market in Indonesia. The danger for the community at large is, of course, the increasing threat of health hazards due to consuming drugs that are not according to standards or that have expired.

Organized crime groups access state apparatus with money in exchange for protection and use of lighter articles. Organized crime groups do not access the state directly, so the relationships formed are not yet perfect political-criminal configurations. Stateorganized crime groups that are formed are also not yet a perfect form, and organized crime groups only co-opt the state function as the enforcement of norms. This then answers the working hypothesis in describing the relationship between the state and organized crime in the fake drug business in Indonesia.

In general, the phenomenon of the distribution of counterfeit drugs in Indonesia can be resolved by the government, but the government must immediately evaluate policies and regulations related to the production and distribution of medicines in Indonesia. Also, before this phenomenon enlarges and extends, the government must reinforce legal sanctions and tighten supervision and action against companies as well as against organized crime that is involved in the production and distribution of counterfeit drugs.

\section{REFERENCE}

1) Bachrach, Peter and Baratz, Morton. S. (1970). Power and Poverty: Theory and Prac1ce. Ew York: Oxford University Press.

2) Benson, B. L., Rasmussen, D. W., \& Sollars, D. L. (2000). Entrepreneurial police and drug enforcement policy. Public Choice, 104(3-4), 285-308.

3) Bhaskarabhatla, Ajay. (2018). Regula1ng Pharmaceu1cal Prices in India: Policy Design, Implementa1on and Compliance. Cham, Switzerland: Springer International Publishing.

4) Bradby, Hannah. (2009). Medical Sociology: An Introduc1on. London: Sage Publications Ltd.

5) Briquet, Jean-Louis and Favarel-Garrigues, Gilles (Eds.). (2010). Organized Crime and States: The Hidden Face of Poli1cs. New York: Palgrave Macmillan.

6) Correa-Cabrera, Guadalupe, Keck, Michelle \& Nava, José. (2015). Losing the monopoly of violence: The state, a drug war and the paramilitarization of organized crime in Mexico (2007 - 10). State Crime, 4(1), 77-95.

7) Davidson, Mark. (2011). Pharmaceutical Anti-Counterfeiting: Combating the Real Danger from Fake Drugs. New Jersey: John Wiley and Sons, Inc.

8) Davis, Courtney and Abraham, John. (2013). Unhealthy Pharmaceu1cal Regula1on: Innova1on, Poli1cs and Promissory Science. New York: Palgrave Macmillan.

9) Edelbacher, Maximilian, Kratcoski, Peter C. dan Dobovšek, Bojan (Eds.). (2016).

10) Corrup1on, Fraud, Organized Crime, and the Shadow Economy. Boca Raton: CRC Press.

11) Friedrichs, David O. (2010). Trusted Criminals: White Collar Crime in Contemporary Society, 4th Edi1on. Belmont, CA: Wadsworth Cengage Learning.

12) Gayer, Laurent. (2014). Karachi: Ordered Disorder and the Struggle for the City. New York: Oxford University Press Inc.

13) Gottschalk, Peger. (2014). Policing White-Collar Crime: Characteris1cs of White-Collar Criminals. Boca Raton: CRC Press.

14) Gounev, Philip and Ruggiero, Vincenzo (Eds.). (2012). Corrup1on and Organized Crime in Europe: Illegal Partnerships. New York: Routledge.

15) Ho, Cynthia M. (2011). Access to Medicine in the Global Economy: Internalonal Agreements on Patents and Related Rights. New York: Oxford University Press Inc.

16) Huang, Hua-Lun. (2008). Characteristics and Operational Tactics of Organized Crime. In Frank G. Shanty, Organized Crime: From Trafficking to Terrorism. California: ABC-CLIO Inc.

17) Karstedt, Susanne and Bussmann, Kai-D. (2000). Introduction: Social Change as a Challenge for Criminological Theory. In Karstedt, Susanne and Bussmann, Kai-D (Eds.), Social Dynamic of Crime and Control: New Theories for a World in Transilon. Oxford: Hard Publishing. 
The Politico-Criminal Configuration Relationship between Organized Crime and the State as a Form of StateOrganized Crime in the Phenomenon of Production and Circulation of Counterfeit Drugs in Indonesia

18) Kartika, Sari. (2017, September 15). Indonesia melawan obat palsu. Integrity. Retrieved from https://integrityindonesia.com/id/blog/2017/09/15/melawan-obat-palsu-di-indonesia/.

19) Kelly, Robert J. (1999). The Upper world and the Underworld: Case Studies of Racketeering and Business Infiltra1ons in the United States. New York: Springer.

20) Ketchley, Neil. (2017). Egypt in a Time of Revolu1on: Conten1ous Poli1cs and the Arab Spring. Cambridge: Cambridge University Press

21) Kleiman, M. A. R., \& Smith, K. D. (1990). State and local drug enforcement: in search of a strategy. Crime and Jus1ce, 13.

22) Morris, J., \& Stevens, P. (2006). Counterfeit medicines in less developed countries. Interna1onal Policy Network, 3-8.

23) Pisano, Douglas J. (2003). Essen1als of Pharmacy Law. Boca Raton: CRC Press.

24) Scheb, John M. and Scheb II, John M. (2011). Criminal Law and Procedure, 7th Edi1on. Belmont, CA: Wadsworth.

25) Shelley, Louise. (2007). Georgian Organized Crime. In Shelley, Louise, Scog, Erik R. \& Laga, Anthony, Organized Crime and Corrup1on in Georgia. New York: Routledge.

26) Strauss, Anselm., \& Corbin, Juliet M. (1998). Basic of Qualita1ve Research: Techniques and Procedures for Developing Grounded Theory. California: SAGE Publication.

27) Syaodih, Nana. (2006). Metode Peneli1 an Pendidikan. Bandung: Remaja Rosda Karya. Tombs, S. and Whyte, D. (2010). Crime, Harm and Corporate Power. In J. Muncie, D. Talbot \& R. Walters (Eds.), Crime: Local and Global. Cullompton: Willan Publishing.

28) Treverton, Gregory F., dkk. (2009). Film Piracy, Organized Crime, and Terrorism. Santa Monica, CA: RAND Corporation.

29) Walters, Reece. (2011). Eco Crime and Genelcally Modified Food. A GlassHouse Book. New York: Routledge. 